\title{
Miranda
}

Revue pluridisciplinaire du monde anglophone /

Multidisciplinary peer-reviewed journal on the English-

speaking world

$14 \mid 2017$

Early American Surrealisms, 1920-1940 / Parable Art

\section{Americanizing Surrealism: Cultural Challenges in the Magnetic Fields}

\section{Anne Reynes-Delobel and Céline Mansanti}

URL: http://journals.openedition.org/miranda/9759

DOI: 10.4000/miranda. 9759

ISSN: 2108-6559

Publisher

Université Toulouse - Jean Jaurès

\section{Electronic reference}

Anne Reynes-Delobel and Céline Mansanti, "Americanizing Surrealism: Cultural Challenges in the Magnetic Fields", Miranda [Online], 14 | 2017, Online since 03 April 2017, connection on 16 February 2021. URL: http://journals.openedition.org/miranda/9759 ; DOl: https://doi.org/10.4000/miranda.9759

This text was automatically generated on 16 February 2021.

\section{(-) $\triangle \Theta \Theta$}

Miranda is licensed under a Creative Commons Attribution-NonCommercial-NoDerivatives 4.0 International License. 


\title{
Americanizing Surrealism: Cultural Challenges in the Magnetic Fields
}

\author{
Anne Reynes-Delobel and Céline Mansanti
}

1 Any attempt at surveying American Surrealisms is likely to attract a certain amount of suspicion insofar as there has never existed such a thing as a large organic Surrealist movement in the United States. Instead, Surrealist activity in America has been characterized by interactions, exchanges, and influences in a number of heterogeneous fields, at different times and in different forms. Despite these discontinuities, between 1920 and 1940, contact with European Surrealism significantly shaped the cultural agendas of American writers and artists. As Dickran Tashjian showed in his 1995 seminal cultural history of Surrealism in America, the American avant-garde's ambivalent response to Surrealism "skewed the politics of American culture at its deepest reaches" (Tashjian 9). Over the past two decades, scholarly interest in the topic has continued to expand our understanding of the variety of practices carried out by American modernists in the attempt to forge their vernacular version of Surrealism and rearticulate the cultural life of the interwar United States.

2 The articles included in this issue of Miranda present recent scholarly research in the field of literary and visual modernism. They cover a range of subjects, from the role played by avant-garde little magazines to the idiosyncratic Surrealist poetics developed by a number of American writers, poets, and artists. They also reveal important but little-known aspects of the involvement of Breton and other fellow exiles in American culture and politics. The overall objective is to survey the affinities and tensions which marked the assimilation of Surrealism in the United States, and contributed an important chapter to the history of transnational modernism.

\section{Surrealism as cultural challenge}

3 European Surrealist exile in the United States led to the expansion of Surrealism through significant interactions within a wider network of artists, writers, and intellectuals. These exchanges and encounters were greatly facilitated by the work of a 
number of curators and art dealers, such as Peggy Guggenheim, Julien Levy, A. Everett Austin Jr., and Alfred H. Barr who introduced European visual Surrealism in New York as early as 1931. Over the next decade a series of exhibits and publications fueled the interest of the American public. These included the 1931 Newer Super-Realism exhibition at the Wadsworth Athenaeum in Harford, Connecticut, the 1932 Surréalisme show at the Levy Gallery in New York, and the 1936 Fantastic Art, Dada, Surrealism landmark exhibition at the Museum of Modern Art. In this context, the arrival of exiled Surrealists in New York in 1941 was greeted with a feeling of goodwill and curiosity on the part of the younger generation of American artists who viewed Surrealism as an opportunity, using it as a chance to develop idiosyncratic forms of expression (Durozoi 393). Coincidently, Surrealism transplanted to the New World underwent changes on American soil, absorbing and reflecting aspects of American life and culture.

American interest in Surrealism was characterized from the onset by an attempt to secure a footing in the cultural terrain so as to define a distinctly American artistic identity. In 1932-43, as has been pointed out by Stamatina Dimakopoulou, the Museum of Modern Art's policies sought to include Surrealism "to align a neglected American cultural history with the sources of modern art" (Dimakopoulou 748). Alfred Barr's decision to sponsor Disney animation art, commercial and folk art, as well as work by children and "the insane" in his major 1936 exhibition Fantastic Art, Dada, Surrealism provides a case in point. A decade earlier, several modernist little magazines had already wanted to absorb European Surrealism so as to express the idea of cultural appurtenance and identity. Throughout the 1920s and 1930s, European-based American journals, such as The Little Review, Broom, and transition, brought French surrealism both in French and in English - to an American readership with a view to encouraging transatlantic exchanges and stimulating the imagination of the younger generation of American writers and artists. For their editors, however, the choice to live in Europe was not to imitate European literature but to create a new form of writing that would revitalize American literature. One of the most enduring of these magazines, transition, went a step further by shifting the responsibility of re-articulating cross-national identities into the hands of the young American avant-garde.

5 Stemming from the Parisian-based magazine culture, transition (1927-38) was instrumental in publishing some fifty pieces by Breton, Aragon, Desnos, Eluard, and others. Yet its main editor, Eugène Jolas, was keen not to be identified as one of Breton's followers but rather as the promoter of an imaginary of circulation and exchange within the networked framework made possible by the magazine format. Shunning Bretonian doctrinaire programmes and established hierarchies, transition fueled a process of differentiation based on the creative possibilities offered by the American language. At the same time, a series of forums, letters, and questionnaires prompted contributors to define cultural differences on a variety of topics, including Europe, America, and Surrealism. Such editorial activism quickly delivered results: as early as 1928, Paul Bowles, Wayne Andrews, William Closson Emory, Whit Burnett, Leigh Hoffman, Charles Tracy, and Murray Godwin had published Surrealist writings in transition. In her analysis of the journal's literary and cultural achievements, Céline Mansanti has pointed out the main characteristics of this production, including a shift away from a literature derived from the unconscious towards an aesthetics of the fantastic, as well as an emphasis on film scenario and the fairy tale. Taking her cue from Jonathan Veitch, who has associated the term "Super-Realism" - first used by 
West in 1931 - with "excessive realism," Mansanti has examined the "Super-Realist" path cut by William Carlos Williams, Nathanael West, and Murray Godwin in their exploration of the material, even scatological, body (Mansanti 200-49). In fostering these literary experiments, as Peter Brooker has noted, transition helped shape the cultural environment in which View magazine was born, in 1940, "when the exchange with Europe was enacted on the American soil" (Brooker 634).

Launched in New York in September 1940 by the Mississippi-born poet Charles Henri Ford, View, though not a Surrealist magazine, published the major productions of the movement and served as the main forum for exiled Surrealists until 1942, when Breton decided to found VVV. Ford, whose first Surrealist "thrill" came through transition, turned his attention to the "little magazine" with the aim of emulating inclusive and collaborative exchanges. An earlier editorial venture, Blues, which Ford edited from Mississippi in 1929-30, had provided a textual space for a young generation of poets who drew their inspiration from the international avant-gardes. Although several contributions to the magazine reveal the distinct influence of the surrealistic experimentations carried out by Soupault and Breton, Ford was more intent on rejuvenating the American modernist idiom than on promoting Surrealism. His prolonged stay in Paris in the 1930s gave him an opportunity to meet the French Surrealists and socialize with the members of the expatriate circle. This first-hand experience further shaped his approach to a form of avant-gardism bringing together "fashionable transatlantic elements and neglected aspects of American talent" (Brooker 635).

7 The first issue of View appeared several months before the arrival of the Surrealist exiles in New York. Through a combination of literature, visual art, and cinema, the journal's main objective was to bridge the gap between avant-garde and popular culture. ${ }^{1}$ Beyond merely encouraging a dialogue between European and American surrealistic views and experiments, Ford intended to use Surrealism as a means to investigate and reclaim marginalized cultural forms. In a context marked by a growing sense of disillusionment towards American conservatism and capitalism amongst writers and artists, View's strong interest in naïve poetry and art, the fantastic, and the macabre stressed the importance, as Fabrice Flahutez has noted, "of a sort of paradigm of the poetic subconscious which was deeply rooted in the American culture" (Flahutez 24).

\section{An American fantastic}

8 The publication of the "Americana Fantastica" issue of View in January 1943 left no ambiguity as to the magazine's cultural politics. The cover, designed by Joseph Cornell, was a collage juxtaposing diverse iconic elements of popular culture (Native Americans, trapeze and high wire artists, King Kong atop the Empire State Building, and so on) and the natural sublime (Niagara Falls). This pictorial story read as a poetic metaphor of the possibilities offered by indigenous material to the imagination. In an editorial article, Parker Tyler, a former contributor to transition, defined the American fantastic as an integral part of the romantic spirit, as Jolas had done before him. He also stressed its subversive and transgressive character:

The fantastic is the inalienable property of the untutored, the oppressed, the anarchic, and the amateur, at the moment when these feel the apocalyptic hug of 
contraries. (...) It is the real Constitution of a romantic State, and, being primarily spatial in nature, organizes, without permission, boundaries that arbitrarily include all features of the social. (Tyler 1943, 5)

"The monstrous," he wrote, "is produced by desire without reason. (...) The child's desire for the moon is monstrous, fantastic and violent." View documented the monstrous with a degree of relish which war-refugee artists from Europe may have found disconcerting. For instance, an essay by Marius Bewley on the American macabre was illustrated with a medical photograph of a face wound. Another picture of maimed limbs was captioned: "Photograph your injuries at once. You cannot photograph your pains but you can photograph the wound. Time heals everything - so photograph it now." In this essay, Bewley identified the macabre as the result of the conditions in a pioneer society:

The limits of American expansion were achieved by the exploitation of humans, the degradation of slaves, the extermination of natives, the careful cultivation of brutality and callousness. (...) But it was necessary that such rugged characteristics should appear, not as perversions, not as macabre, but as the natural expressions of a robust spirit. (Bewley 18)

11 Being "in close communication with the changes in national temperament," the macabre sat comfortably in a tradition running in American literature from Crevecoeur to Hawthorne and Poe, Dick Tracy, and pulp fiction. In the mid-1920s, in a piece of improvisation entitled "Rome," William Carlos Williams had extolled the murderous and the perverted element in American life as a way to reach for a sense of poetic reality. A few years later, in the same spirit, he praised Nathanael West's use of newspapers as documentary evidence in Miss Lonelyhearts (1933) as an example of how writing could drag the known up from the unknown and thus reveal "our daily lack of depth in thought of others" (Williams 1933, 1-2). In leaving violent images almost bald, West combined the narrative efficacy of the comic strip with the naturalistic tradition of John Dos Passos and James T. Farrell.

12 As Mike Weaver has observed, acceptance of the aggression and violence in the American character drove writers to stress the importance of the sensual in art. In a letter written to William Carlos Williams in 1941, Robert Motherwell proposed to americanize Surrealism in four propositions, ${ }^{3}$ the second of which insisted on "the dignity and value of personal feelings" and "the felt-content of the organism's experiencing." Williams could not but agree. His foremost concern, Weaver stresses, was the correct naming of internal events (Weaver 140). In his Novelette, partially published in transition in 1930, Williams had also specifically associated his own notion of automatic writing with corporeal "relaxation" and "relief," an idea ${ }^{4}$ he emphasized again in an article issued in View over a decade later:

Surrealism is just that: Don't try. An incentive to creation. Only in the unknown lies the inevitable. To me Surrealism is to disclose without trying. Only thus shall we get a healthy literature. (...) OMIT the deductions. There's a nice word, OMIT. It looks odd. Truncated. Rather close to VOMIT. It might save the world. Omit trying too hard, just enter and look about and do, etc., etc. (Williams 1942, 13) 

description of Basno Snell's mock-picaresque journey into the mucous innards of the Trojan horse in Nathanael West's 1932 novel and, in a lesser measure, in Murray Godwin's Work on Sidetrack, serialized in transition in 1927 and 1929 (Mansanti 216-228).

In the letter addressed to Williams, Motherwell's fourth proposition that the American use of the dialectic method would effect "a union between normal consciousness and the unconscious" was also in agreement with Williams's and Tyler's views. According to Tyler's definition: "Surrealism combines in practice the representational value of the image (imagism) and the symbolic value of the image (symbolism) in a sort of dialectical play of values" (Tyler 1940, 44). Yet, as Marjorie Perloff has noted, such dialectic is almost diametrically opposed to the Surrealist definition of "pure psychic automatism" as resting on "neglected forms of associations, in the omnipotence of the dream, [and] in the disinterested play of thought" (Perloff 1996, n.p.). This skewed understanding of Surrealist dialectic (between the literal and the symbolic) casts another light on View's editorial choices. It explains, for instance, the journal's support of the Neo-Romantic painting of Tchelitchew. More broadly, it also indicates that, while welcoming Surrealism as a way to steer American art and writing away from the political sense of revolution which had dominated the 1930s, Williams and Tyler, like most of View's contributors, did not want to be submerged by a foreign movement. As Motherwell's third proposition made clear, their "revolutionism" would not align with Surrealism forays into the unconscious but would cut its own "trail," guided by a sense of "increased consciousness of the possibilities inherent in experiencing."

Yet, despite its divergence from European Surrealism, View played a significant role in the development of the movement after 1940. Not only did Ford's journal facilitate exchanges and collaboration between European and American writers and artists, but it also introduced exiled Surrealists to the American context. Through the magazine, emigrant Surrealists discovered marginal or undervalued forms of popular expressions, and their potential for resistance to the mainstream. As Flahutez has observed, the concept of the "Great Transparent Ones" (Grands Transparents) developed by Breton and Matta in the 1940s, owes much to their growing familiarity with American mass culture - including science fiction, the fantastic, and the immensely popular pulp fiction magazines: "Ces Grands Transparents que Matta et Breton tentent de formuler sont puisés à la source d'auteurs américains et répondent à cette surenchère - notamment dans la culture populaire - de créer des mythes" (Flahutez 203). ${ }^{6}$ In facilitating the opening of Surrealism to American vernacular culture, View contributed to expanding the "limits not frontiers of Surrealism."7

\section{Charting "impure" territories}

Despite their awareness of the creative possibilities offered by American mass culture and popular forms of expression the European exiles did not display any particular interest in American material civilization per se. Instead, during the course of the 1940s, they went on to elaborate a new "global consciousness" for their time by forging a new poetics of space which combined various European esoteric traditions with North Amerindian cosmogony. The discovery of new landscapes and cultures had a tremendous impact on their view of art and magic. Direct contact with New York art dealers and curators also helped them further their knowledge of Native American - 
and more specifically Northwest Coast and Southwest - myths and symbols. Soon after their arrival in New York, Amerindian mythologies crystallized their theoretical choices and prompted their tactical moves. ${ }^{8}$ Following a different route, the young American moderns who were intent on creating literature and art out the phenomena of American popular culture - vaudeville, slapstick, comic strips, cartoons, cinema, and the advertising industry - focused their attention of the kaleidoscopic life of the metropolitan, technological landscape.

In the second half of the 1920s and the early 1930s, Los Angeles became one of the privileged loci of an investigation of reality which blended surrealistic fantasy with nightmarish grotesquerie. In Hollywood, photographers Will Connell and William Mortensen combined photographic manipulation with cinematographic techniques to lampoon the film industry and mock Tinseltown kitsch. The city's modernity and "impurity" made it the very social and cultural opposite to the nationalist standards and values of the New Deal era. Moreover, by tapping into popular taste and exploring images of sex and violence that took their cue from the Universal monster movies of the 1920s and 1930s, Mortensen made himself particularly anathema to Ansel Adams and the Group f/64 exponents of "simple and direct presentation through purely photographic methods". ${ }^{9}$

In Nathanael West's 1939 novel, The Day of the Locust, Los Angeles is also placed in a diametrically antithetical relationship to the ideal of an "organic folk culture" emphasized by Regionalism. West used surrealistic montage techniques and convoluted imagery to turn the cityscape into the setting of a bizarre, endless masquerade. The novel describes how human beings are relentlessly incorporated into the modern commercialized, consumerist, and mechanized mass society of the metropolis. The only exceptions are foreign elements like Miguel, the "Mexican," who is made immune to assimilation into a nationalist agenda by his very "un-Americanness". ${ }^{10}$ In the novel's geography, California, like much of the American West, remains a sort of eccentric outpost in the nation's mind. Pursuing this line of reasoning, other writers came to identify the region with "the dream-ideal" of [their] age" and the very model of authenticity at a time when deceit and counterfeit were rampant. In "California Chronicle," published in View in 1940, Edouard Roditi wrote, reversing perspectives: "I hope that Hollywood may continue unchanged, a spot of non-sense in a world which is rapidly lapsing into gloomy ages of utter seriousness and hypocrisy" (Roditi 4).

In Troy Garrison's or Brion Gysin's depictions of the modern metropolis the urban places and spaces become social critiques. Garrison's "Plaza of the Psychopathic Angels" and Gysin's "That Secret Look" were both published in an issue of View edited by Nicolas Calas in $1941^{11}$. Garrison's sordid depiction of San Francisco underscores the unglamorous side of the City by the Bay: "The southward tides of traffic and pedestrians move past rotted ancient structures whose windows reflect no light, past what must be the oldest cafe ... and, some five or six blocks away, flow through the backwash of 'B-girl' cafes, burlesques, pawnshops, and human wreckage" (Garrison, 4). Gysin's portrayal of New York City espouses the viewpoint of an outsider to picture the squalid dereliction beneath the garish sights and sounds of the city:

"A town that greets you standing up," says a writer, and sure enough between the skyscrapers hand festoons of popcorn and ropes of candy beads. Chased by the searchlights of a World Premiere, or is it a 'Spectacle in the Sky' - a mock air raid, one of the rainbows that breathe up from the miasmic Times Square; the exhilaration of a million desires that carpets the sky from the seventeenth floor on 
up ... The streets below are like the stream of 'The Old Mill' or 'The Tunnel of Love' at Luna Park or Coney Island through whose fog of carbon monoxide you are swept clutching your neighbor, past bright tableaux; the desert island, the cemetery by moonlight, the axe murderer in the kitchen or famous scenes from fiction. (Gysin, 7)

\begin{abstract}
often, bathos - of Being as it is grotesquely contorted within the cartoonish dimensions of mass culture" (Veitch, xiii).
\end{abstract}

\title{
Critical pessimism and artistic responsibility
}

The convergence of social concerns and surrealistic aesthetics in American modernist literature can be traced back to the early 1920s, when the exponents of an American "Super-Realism" defended the use of dark humor and pastiche as a way to encourage critical pessimism and artistic responsibility. The project emerged mainly in response to a fierce attack launched in January 1924 in American Mercury by H.L. Mencken and George Jean Nathan against a group of young writers and critics associated with "cosmopolitan" little magazines, including Malcolm Cowley, Matthew Josephson, Waldo Frank, Kenneth Burke, and Robert M. Coates. Using little magazines - such as Broom, Aesthete 1925, The Little Review, and later transition - as their main weapon, the group retaliated by fostering a poetics which rejected both the form of cultural progressivism expressed in Mencken's cynical journalistic realism and the model of unity and cohesion defended by Waldo Frank in Our America (1919). Instead, as Jonathan Eburne has convincingly demonstrated, it demanded "a degree of critical observation and distance that acknowledged the socially-verifiable presence of the grotesque, the absurd, and the dangerous, rather than sought to purge them from American artistic and intellectual life" (Eburne 537).

An example can be found in Robert M. Coates's The Eater of Darkness, published in Paris by Robert McAlmon's Contact Press in 1926. The novel, rife with pulp and modernist allusions, is an experiment in seeing. It tells the story of Charles Dograr a young artist who has just returned from Paris to embark on a killing spree across New York City with a strange, old man, the inventor of a sort of laser-like death ray. The series of objects the machine looks through humorously conflates major figures of the artistic and literary scene with the products of consumer culture:

.... bottle of glue ... the hands of the reader an orange ... a pack of cards a glass eye two felt slippers the $C$ in a Chop Suey sign a cigarette holder an umbrella Reginald Marsh a bottle of gin Cigar store coupons, H.L. Mencken, a stiletto, Kenneth Burke, a stethoscope, a Martini cocktail ... (Coates, 1929 29-32)

Yet, beneath the humor and modernist hijinks (including interpolated captions, fragmented syntax, unconventional typographic arrangements, an annotated diagram, listings, and footnotes) is a rather grim diagnosis of contemporary society. The text overwhelms the reader with the sensory overload of the urban, modern world, thus hindering any depth of understanding. Further degradation of analytical and creative ability is also presaged by the commodification of literary society illustrated by the metonymical objectification of such literary figures as Dreiser, Burke, or Mencken. As the book's central metaphor-the "x-ray bullet"- suggests, the artist's sole function is to record, machine-like, the violent, grotesque effect of urban capitalist consumer culture, not attempt to change them. In other words, to posit "reform as a project 
toward which art [can] aim-but which it [can] not itself fulfill" (Eburne 523). Like other exponents of a literary "Super-Realist" poetics, such as Williams and West, Coates advocated a strong political and social consciousness, albeit one devoid of an affective content or spiritual telos.

In the realm of the visual arts, other attempts to appropriate Surrealism to the goals of social criticism included the experiments carried by a group of artists, sometimes referred to as Social Surrealists, whose principal exponents were O. Louis Guglielmi, Walter Quirt, and James Guy. As early as 1933, as Ilene Fort has underlined, these painters chose to confront national problems, including issues of unemployment, poverty, and workers' rights, by using surrealistic techniques. Although they were not the product of psychic automatism but were based instead, as Ilene Fort has noted, on "life in the real, physical world," their paintings were "as frightening and hallucinatory as European artists' more personal vision while retaining their focus on social problems." Overall, Fort writes, "the radical esthetic of Surrealism enabled American artists to intensify their socio-political statements and thus to present familiar aspects of American life in a new perspective" (Fort 8).

\section{Strange crossings}

Nevertheless, not all early American surrealistic experiments aimed at heightening critical consciousness and political awareness. An intriguing exception is the series of objects created in the early 1930s by artist Joseph Cornell and photographed by Lee Miller in 1933. One of them in particular, soberly titled Object by Joseph Cornell ${ }^{12}$, provides a window into the ways in which these American artists seized upon the experiments with objects they found fomenting in European Surrealism to launch into a highly conscious commitment to exploration and clarification of their vernacular culture and imagination.

Both Cornell and Miller were only loosely affiliated with the Paris group. Cornell, though he refused the Surrealist moniker, was hailed by Julien Levy as "one of the very few Americans at the present time who can fully and creatively understands the surrealist viewpoint" (Levy 28). His receptiveness to the surrealist idiom, in particular to Max Ernst's collage techniques, attracted Levy's attention. The gallerist included several of the young artist's collages in his pioneering Surrealism exhibition of January 1932 before giving him his first solo show by the end of the same year. ${ }^{13}$ For this exhibition, Cornell made about six large "bell jar" objects, three of which he requested Miller - whom he had met through Levy - to photograph in her studio a few weeks later. One of these assemblages stands out among the others. Its composition seems less strictly aligned with Surrealism's figurative and natural iconography, such as hands, eyes, insects, or metronomes. Besides, its inspiration conflates Cornell's interest in surrealist psychic automatism and his passion for vernacular discarded Victorian artifacts.

Object by Joseph Cornell is a tall bell jar - a decorative object commonly used in nineteenth-century households to display dried flower bouquets, wax fruits or foliage, stuffed birds, model ships, clocks, and other handicrafts - containing an angel doll's head placed in a brass cup which is itself delicately balanced on the top rim of a wine glass. ${ }^{14}$ The doll's head is punctured by three needles with white threads attached to it. These threads hang loosely over the rim of the glass and their trailing ends are looped 
around its base. The object's composition and the way it is photographed lay the emphasis on the structure within the structure, thus abstracting the idea of pain associated with the needles into a sealed, crystalline universe. Miller's ability to create curves, flares, and tiny reflections similar to stellar flashes gives the uncanny assemblage a peculiar aura. The combination of three-dimensional montage and photography forces a stronger sort of focalization - the circumscribed space into which the viewer peers seems to contain a mental image conjured up from infinite space.

Photographing a severed head in a bell jar was nothing really new. As early as 1926, Claude Cahun had already done it in a series of self-portraits. In 1930, Man Ray and Lee Miller, who were then working together in Paris, collaborated on a photomontage portraying the head of a friend of Miller's in a domed glass bell. ${ }^{15}$ While this previous experiment may have served as inspiration or influence for Cornell and Miller, ${ }^{16}$ the bell jar object featuring the doll's head owes much to the artist's personal interests and beliefs. By bringing together different basic household items, as if for some kind of simple science experiment, the assemblage points at Cornell's autodidactic experience and polymathic tendencies. Moreover, if the needles and threads hint at the power of the surrealist object to puncture the thin veneer of reality and call forth a higher state of perceptual intuition, they may also contain an allusion to the Christian Scientist belief in the power of Mind over the physical conditions of the body ${ }^{17}$ and, accordingly, to Cornell's own belief in the "healthier possibilities" of Surrealism ${ }^{18}$. Preserved in Miller's photograph, Object by Joseph Cornell is a fascinating combination of highly personal beliefs and shared aesthetic values resulting from the two artists' momentary association in the same sub-surrealist world. The eerily beautiful image they created shows how surrealistic artistic practices intersected and were renegotiated across transcultural lines, making transnational surrealism more akin to a shifting constellation than an organized network.

As this brief overview has attempted to suggest, early American Surrealisms were closely connected to the 1920s and 1930s international, transatlantic little magazine culture. They participated in a crucial effort to shape a vernacular modernism which would retain the critical, oppositional edge of the European avant-gardes. While this movement gained significant momentum with the arrival of the European exiles in New York at the beginning of the 1940s, it was deeply rooted in the 1920s and early 1930s when the debate about "nativist" and "internationalist," or "cosmopolitan" and "universalist" issues contributed to a remapping of the geographies of American literary modernism. In light of these facts, the notion that "the American contribution to Surrealism only occurred in New York at the end of the 1930s" (Lévy 20) seems slightly misconceived. Based on a specifically local and indigenous understanding of the fantastic, American Surrealism was also characterized by its deep commitment to political and social issues. Its complex, biased relationship with European Surrealism has often been compared to an unresolved set of dialogues. Yet, it was also marked by decisive, fruitful exchanges which profoundly influenced the historical development of Surrealism. 


\section{BIBLIOGRAPHY}

The following articles suggest new insights into this important moment in the dialogue between America and Europe. A bibliography of primary and secondary sources rounds out this cluster of essays.

Bewley, Marius. “On the American Macabre.” View 5:3 (October 1945), 7-8, 18, 20.

Breton, André. “Manifeste du surréalisme.” 1924. In Manifestes du surréalisme. Paris: Gallimard, 1971.

---. “Limites non-frontières du surréalisme." 1936. Nouvelle Revue Française (1 February 1937): 48. Rpt. in Surrealism. Ed. H. Read. London: Faber and Faber Limited, 1971.

---. 'Drawbridges' [1962], preface to Pierre Mabille, Mirror of the Marvelous: The Classic Surrealist Work on Myth [1940/1962]. Trans. Jody Gladding, Rochester, Vermont: Inner Traditions, 1998.

Brooker, Peter. "Cross-Currents: America and Europe." In The Oxford Critical and Cultural History of Modernist Magazines, Volume II: North America 1894-1960. Ed. P. Brooker and A. Thacker. Oxford: Oxford University Press, 2012. 630-35.

Coates, Robert M. The Eater of Darkness. 1926. New York: Macauley, 1929.

Durozoi, Gérard. Histoire du mouvement surréaliste. Paris: Hazan, 2004.

Dimakopoulou, Stamatina. "Europe in America: Remapping Broken Cultural Lines: View (1940-7) and VVV (1942)." In The Oxford Critical and Cultural History of Modernist Magazines, Volume II: North America 1894-1960. Ed. P. Brooker and A. Thacker. Oxford: Oxford University Press, 2012. 737-758. Eburne, Jonathan P. “Anti-Menckenism: Nathaniel West, Robert E. Coates and the Provisional Avant-Garde." Modern Fiction Studies 56:3 (Fall 2010): 518-543.

Fort, Ilene Susan. “American Social Surrealism.” In Archives of American Art Journal 22:3 (1982): 8-20.

Gano, Geneva M. "Nationalist Ideologies and New Deal Regionalism in The Day of the Locust." Modern Fiction Studies 55:1 (Spring 2009): 42-67.

Garrison, Troy. 1941. “Plaza of the Psychopathic Angels.” View 1:6 (June 1941): 4.

Gysin, Brion. “That Secret Look.” View 1:7-8 (October-November 1941): 7-8.

Hoving Kirsten. “Joseph Cornell's First Soap Bubble Set.” American Art 20:1 (2006):14-35. 14-35.

Levy, Julien. “Surrealism.” New York: Black Sun Press, 1936.

Lévy, Sophie, "Sympatheric Order," in American Artists in Paris, 1918-1939. A Transatlantic AvantGarde. Ed. Sophy Lévy. Berkeley, Los Angeles: University of California Press / Giverny: Musée d'Art américain, 2003. 15-21.

Mansanti, Céline. La revue transition (1927-1938) : le modernisme historique en devenir. Rennes : Presses Universitaires de Rennes, 2009.

Paalen, Wolfgang. Preface. DYN. Amerindian Number 4-5 (December 1943).

---. “Book Reviews: Exil. Fata Morgana. VVV.” DYN. Amerindian Number 4-5 (December 1943): 81.

Perloff, Marjorie. “Late Late Modern.” William Carlos Williams Review 22:1 (Spring 1996).

Accessed through: http://epc.buffalo.edu/authors/perloff/parker.html 
Reynes-Delobel, Anne. "Scénographies de la relation forte : de quelques objets surréalistes sous cloche" in Fictions modernistes du masculin/féminin 1900-1940. Ed. A. Oberhuber et A. Arvisais. Rennes: Presses universitaires de Rennes, 2016. 227-49.

Roditi, Edouard. “California Chronicle.” View 1:3 (October 1940): 4.

Suárez, Juan A. "View (1940-47), the Avant-Garde, and the Uncertain Life of Objects: Criticism as if Fragments Mattered.” Miscelánea: A Journal of English and American Studies 18 (1997). Online.

Tashjian, Dickran. A Boatload of Madmen, Surrealism and the American Avant-Garde 1920-1950. New York: Thames and Hudson, 1995.

Tyler, Parker. “Americana Fantastica.” View 2:4 (January 1943): 5.

Veitch, Jonathan. American Superrealism, Nathanael West and the Politics of Representation in the 1930s. Madison: University of Wisconsin Press, 1997.

Weaver, Mike. William Carlos Williams: The American Background. Cambridge: Cambridge University Press, 1971.

West, Nathanael. The Dream Life of Basno Snell. Paris: Contact Editions, 1931.

---. Miss Lonelyhearts. New York, Liveright, 1933.

---. The Day of the Locust. New York: Random House, 1939.

Williams, William Carlos. “A Novelette.” 1932. In Imaginations. Ed. Webster Schott. New York: New Directions, 1970. 272-306.

--- "Sordid? Good God!" Contempo 3:2 (25 July 1933): 5, 8.

---. "Surrealism and the Moment." View 2:2 (May 1942): 13.

\section{NOTES}

1. As Dimakopoulou has observed, View emerged in New York at the same time as Abstract Expressionism. Ford's editorial choice set the journal in direct opposition to Clement Greenberg's views of the antagonist relation between the avant-garde and mass culture (Dimakopoulou 738).

2. In his preface to Pierre Mabille's Mirror of the Marvelous (1962), Breton remarked that "nothing defines [the marvellous] better than setting it in opposition to the 'fantastic'. The fantastic nearly always falls under the order of inconsequential fiction, while the marvellous illuminates the further extreme of vital movement and engages the entire emotional realm" (xvi). In other words, the marvelous emerges from reality, whereas the fantastic opposes reality. Whereas the fantastic relies on visual shock, the marvelous emerges primarily from language. American surrealist phantasmagorias are usually safely contained within the limits of a parallel world, whether it is a dream or a scenario; reality itself is not radically put into question.

3. Letter from Robert Motherwell to W.C. Williams (3 December 1941). Qtd. in Weaver (139-40).

4. "For relaxation, relief. To have nothing in my head-to freshen my eye by that till I see, smell, know and can reason and be." A Novelette. transition 19-20 (June 1930): 286.

5. Significantly, in 1932, the slogan of the second series of Williams and West's Contact magazine was, already, "Contact will attempt to cut a trail through the American jungle without the use of a European compass." Contact 1 (February 1932): n.p.

6. "While tapping into American pulp culture, the Great Transparent Ones which Breton and Matta were trying to formulate also resisted American mythmaking frenzy." On the influence of American pulp fiction and fantasy on Surrealism, see Flahutez (200-218). 
7. The phrase refers to "Limites non-frontières du surréalisme," a speech given by Breton at the New Burlington Galleries in London, in June 1936.

8. In April 1942, in Mexico City, Wolfgang Paalen launched the journal Dyn which aimed at integrating "Amerindian forms into the consciousness of modern art" (Paalen 1943, n.p.). By pursuing serious scientific and anthropological interests, Dyn meant to break away from what Paalen felt was excessive poetic interpretation in the Surrealist approach to reality. In his eyes, reliance on the idealized exotic Other and the "picturesquely local" had rendered Breton and his circle "incapable of assimilating what there [was] of importance in American thought" (Paalen 1943,81 ). Breton and Duchamp retaliated by making the issue of Indian art and mythology one of the core elements in the search for a new collective myth, as is obvious in their decision to publish anthropological and ethnological essays in the newly-founded VVV magazine (June 1942), and to combine surrealist objects and Amerindian art in the First Papers of Surrealism exhibition (November 1942).

9. Quoted from the Group f/64 1932 manifesto.

10. For an analysis of West's preoccupation with the nationalist thrust in regional writing, see Gano (2009).

11. On this topic, see also Suárez (1997).

12. This bell jar object no longer exists. Cornell sent a print of Miller's photograph to André Breton. Another one was exhibited at the show Surrealism: Objects Photographs Collages Documents presented at the Zabriskie Gallery in New York, in 1936. The original negatives are held in the Lee Miller Archives, East Sussex, England.

13. "Objects by Joseph Cornell: Minutiae, Glass Bells, Shadow Boxes, Coups d'Oeil, Jouets Surréalistes," Julien Levy Gallery. New York, November 1932.

14. Cornell later recycled several of these items into his first Soap Bubble Set (1936). For an enlightening discussion of the Soap Bubble Set series, see Hoving (2006).

15. Man Ray's Hommage à D.A.F. de Sade and its variant (attributed to Miller), Tanja Ramm and Bell Jar: Variant of Hommage à D.A.F. de Sade. Both pictures were made in Man Ray's studio on the same day. A discussion of these bell jar objects can be found in Reynes-Delobel (2016).

16. Unfortunately, neither Cornell nor Miller commented on their collaboration. It is thus impossible to know how much interaction went between them. Interestingly, Miller also photographed another montage by Cornell in another series probably realized at about the same time. This object, entitled, Twelve Needles Dancing on the Point of an Angel, juxtaposes Cornell's head with a number of found or constructed objects including a schooner, a mane of yellow hair, and the small brass cup used in Object by Joseph Cornell. If we do not know which series came first, the two obviously overlap.

17. Cornell converted to Christian Science in 1925 and remained a devout Christian Scientist until his death in 1972. Further examination of Cornell's object would probably entail an investigation into the topic of light, electricity, and magnetism, and the possibility of a crossover from theosophy to Christian Science.

18. "I believe that surrealism has healthier possibilities than have been developed" (Cornell to Alfred Barr, November 13, 1936). 
INDEX

Keywords: American national cultural identity, American surrealism, avant-garde, fantastic, grotesque, interwar United States, literary and visual modernism, little magazines, localism, macabre, magic, modernity, monstrous, popular culture, social criticism, super-realism, technologies, transatlantic exchanges, violence

\section{AUTHORS}

\section{ANNE REYNES-DELOBEL}

Maître de conférences

Aix-Marseille Université

anne.reynes@univ-amu.fr

\section{CÉLINE MANSANTI}

Maître de conférences

Université de Picardie Jules Verne

cmansanti@gmail.com 